\title{
Centropodieae and Ellisochloa, a new tribe and genus in Chloridoideae (Poaceae)
}

\author{
Peterson, P M ; Romaschenko, K ; Barker, N P ; Linder, H P
}

\begin{abstract}
There has been confusion among taxonomists regarding the subfamilial placement of Merxmuellera papposa, M. rangei, and four species of Centropodia even though many researchers have included them in molecular studies. We conducted a phylogenetic analysis of 127 species using seven plastid regions (rps3, rps16-trnK, rps16, rpl32-trnL, ndhF, ndhA, matK) to infer the evolutionary relationships of Centropodia, M. papposa, and M. rangei with other grasses. Merxmuellera papposa and M. rangei form a clade that is sister to three species of Centropodia, and together they are sister to the remaining tribes in Chloridoideae. We provide the carbon isotope ratios for four species indicating that Merxmuellera papposa and M. rangei are photosynthetically C3, and Centropodia glauca and C. mossamdensis are C4. We present evidence in favor of the expansion of subfamily Chloridoideae to include a new tribe, Centropodieae, which includes two genera, Centropodia and a new genus, Ellisochloa with two species, Ellisochloa papposa and E. rangei. The name Danthonia papposa Nees is lectotypified.
\end{abstract}

DOI: https://doi.org/10.1002/tax.604014

Posted at the Zurich Open Repository and Archive, University of Zurich ZORA URL: https://doi.org/10.5167/uzh-56196

Journal Article

Published Version

Originally published at:

Peterson, P M; Romaschenko, K; Barker, N P; Linder, H P (2011). Centropodieae and Ellisochloa, a new tribe and genus in Chloridoideae (Poaceae). Taxon, 60(4):1113-1122.

DOI: https://doi.org/10.1002/tax.604014 


\title{
Centropodieae and Ellisochloa, a new tribe and genus in Chloridoideae (Poaceae)
}

\author{
Paul M. Peterson, ${ }^{1}$ Konstantin Romaschenko, ${ }^{1,2}$ Nigel P. Barker ${ }^{3}$ \& H. Peter Linder ${ }^{4}$ \\ 1 Smithsonian Institution, Department of Botany, National Museum of Natural History, Washington, D.C. 20013-7012, U.S.A. \\ 2 Laboratory of Molecular Systematics, Botanic Institute of Barcelona (CSIC-ICUB), Passeig del Migdia, s.n. 08038, \\ Barcelona, Spain \\ 3 Molecular Ecology and Systematics Group, Department of Botany, Rhodes University, Grahamstown, 6140, South Africa \\ 4 Institute of Systematic Botany, University of Zurich, Zollikerstrasse 107, 8008 Zurich, Switzerland \\ Author for correspondence: Paul M. Peterson, peterson@si.edu
}

\begin{abstract}
There has been confusion among taxonomists regarding the subfamilial placement of Merxmuellera papposa, M. rangei, and four species of Centropodia even though many researchers have included them in molecular studies. We conducted a phylogenetic analysis of 127 species using seven plastid regions (rps3, rps16-trnK, rps16, rpl32-trnL, ndhF, ndhA, matK) to infer the evolutionary relationships of Centropodia, $M$. papposa, and $M$. rangei with other grasses. Merxmuellera papposa and $M$. rangei form a clade that is sister to three species of Centropodia, and together they are sister to the remaining tribes in Chloridoideae. We provide the carbon isotope ratios for four species indicating that Merxmuellera papposa and M. rangei are photosynthetically $\mathrm{C}_{3}$, and Centropodia glauca and C. mossamdensis are $\mathrm{C}_{4}$. We present evidence in favor of the expansion of subfamily Chloridoideae to include a new tribe, Centropodieae, which includes two genera, Centropodia and a new genus, Ellisochloa with two species, Ellisochloa papposa and E. rangei. The name Danthonia papposa Nees is lectotypified.
\end{abstract}

Keywords $\mathrm{C}_{3}$ and $\mathrm{C}_{4}$ photosynthesis; Centropodia; Centropodieae; Chloridoideae; classification; Danthonioideae; Ellisochloa; Merxmuellera; plastid DNA sequences; phylogeny

Supplementary Material The alignment is available in the Supplementary Data section of the online version of this article (http://www.ingentaconntect.com/content/iapt/tax).

\section{- INTRODUCTION}

The subfamily Chloridoideae is a diverse assemblage of $\mathrm{C}_{4}$ grasses containing more than 1420 species that dominate grasslands, and particularly semi-arid grasslands, in eastern and southern Africa, Australia, and southwestern North America (Peterson \& al., 2007). Yet, evolutionary relationships and the classification of Chloridoideae based on the study of molecular characters have, until recently, been poorly investigated $(\mathrm{Pe}$ terson \& al., 2010a). To understand the origins and rise of $\mathrm{C}_{4}$ grasslands, a better interpretation of plant traits via phylogenetic reconstruction is essential (Edwards \& al., 2010). The core species in Chloridoideae share two structural synapomorphies: all exhibit Kranz or $\mathrm{C}_{4}$ leaf anatomy and most have chloridoid bicellular microhairs (broad, short terminal cell the same thickness as the basal cell) present on leaf surfaces. Until recently, Eragrostis walteri Pilg. was thought to be the only $\mathrm{C}_{3}$ species in the subfamily (Ellis, 1984a; Schulze \& al., 1996) but this was apparently based on misclassification within Eragrostis Wolf and the Chloridoideae (Ingram \& al., 2011).

There has been confusion among taxonomists regarding the subfamilial placement of Merxmuellera papposa (Nees) Conert, M. rangei (Pilg.) Conert, and four species of Centropodia Rchb. These taxa had been included in Arundinoideae (Cope, 1982; Clayton \& Renvoize, 1986; Watson \& Dallwitz, 1992) but researchers have found their placement rather nearer
Chloridoideae, possibly as sister to Chloridoideae (Barker \& al., 1999, 2000; Hilu \& al., 1999; GPWG, 2001; Hilu \& Alice, 2001; Roodt-Wilding \& Spies, 2006; Bouchenak-Khelladi \& al., 2008; Christin \& al., 2009). This alignment, within or as sister to Chloridoideae, has not been thoroughly investigated, and recent classifications of the Chloridoideae genera have not included these important taxa (Columbus \& al., 2007; Peterson \& al., 2007, 2010a).

Centropodia is a genus of four species distributed in xeric areas of Africa and Asia (Cope, 1982; Clayton \& Renvoize, 1986; Gibbs Russell \& al., 1990). Ellis (1984b) found that Centropodia glauca (Nees) Cope was anatomically $\mathrm{C}_{4}$ (confirmed by carbon isotope ratios, Schulze \& al., 1996) but at the time both $\mathrm{C}_{3}$ and $\mathrm{C}_{4}$ species were classified within Arundinoideae. Based on the absence of haustorial synergids, Verboom \& al. (1994) were first to report that Centropodia did not align with core Danthonieae (Danthonioideae sensu Barker \& Linder; GPWG, 2001), and $r b c L$ sequence data also support its exclusion (Barker \& al., 1995). Synergid cells are located at the micropylar end of a mature embryo sac in the ovule and in members of Danthonioideae they extend as haustoria beyond the micropyle (Philipson, 1977; Philipson \& Connor, 1984). Centropodia glauca and Merxmuellera rangei were suggested to lie near the base of Chloridoideae where the latter was found to be sister to the former in an rpoC2 sequence analysis (Barker $\&$ al., 1999). Based on possession of adaxial parenchyma and 
development of a terete, cylindrical leaf form, Ellis (1982) suggested that the leaf anatomy of Merxmuellera rangei is clearly distinct and differs drastically from other representatives of the genus. Ellis went on to state, "The leaf anatomy, therefore, indicates that $M$. rangei occupies an isolated position within the genus and possibly suggests that it warrants generic status." Schulze \& al. (1996) verified using carbon isotope $\delta^{13} \mathrm{C}$ ratios that $M$. rangei was a $\mathrm{C}_{3}$ species and this confirms its possession of non-Kranz anatomy as described by Ellis (1982).

Barker \& al. $(2000,2007)$ showed that the genus Merxmuellera Conert, as delimited by Conert (1970, 1971), was grossly polyphyletic, and this was confirmed by the results of Pirie \& al. (2008). Merxmuellera has recently been reduced to seven species by the segregation of Geochloa H.P. Linder \& N.P. Barker (3 spp.), Capeochloa H.P. Linder \& N.P. Barker (4 spp.), and Tenaxia N.P. Barker \& H.P. Linder (8 spp.). Geochloa and Capeochloa with Merxmuellera s.str. form a basal grade relative to the remaining members of Danthonioideae (Linder \& al., 2010). Two species, Merxmuellera papposa and $M$. rangei were used as outgroups in their analyses and were thought reside within Chloridoideae. The GPWG (2001) and Bouchenak-Khelladi \& al. (2008) show the CentropodiaMerxmuellera rangei clade as sister to the remaining chloridoids in their combined molecular consensus trees whereas Hilu \& al. (1999) and Hilu \& Alice (2001) used Centropodia glauca and Danthonia spicata (L.) P. Beauv. ex Roem. \& Schult. as outgroups in their analysis of chloridoid genera. More recently, Centropodia and Merxmuellera rangei have been included within Chloridoideae as sister to the core chloridoids (Christin \& al., 2009; Ingram \& al., 2011).

Character trends in Chloridoideae include $\mathrm{C}_{4}$ leaf anatomy, chloridoid bicellular microhairs on leaf surfaces, a base chromosome number of $x=10$, fruits (caryopses) with nonlinear hila that are usually punctiform or small, embryos with elongated mesocotyl internodes, and two non-membranous (fleshy) lodicules (Soreng \& Davis, 1998; GPWG, 2001; Hilu \& Alice, 2001; Peterson \& al., 2007; 2010a). However, many of these character trends are also seen in the closely related subfamilies Aristidoideae, Arundinoideae, Danthonioideae, Micrairoideae, and Panicoideae of the PACMAD clade (Sánchez-Ken \& al., 2007; Sánchez-Ken \& Clark, 2010). Distinct character trends in Danthonioideae include $\mathrm{C}_{3}$ leaf anatomy, haustorial synergids (mentioned previously), a ciliate ligule, the presence of an embryo mesocotyl, a several-flowered spikelet with, if 1- or 2-flowered, a rachilla extension, usually distinctly separated style bases, and the absence of chloridoid microhairs (GPWG, 2001). Chloridoideae and Danthonioideae were found to be sister to each other with moderate bootstrap support $(\mathrm{BS}=81)$ in Bouchenak-Khelladi \& al. (2008) and with Bayesian support (PP $=0.88$ ) in Ingram \& al. (2011). The Chloridoideae stem group age has been indicated to be $32( \pm 4.4) \mathrm{Ma}$ (Christin \& al., 2008).

In our study we provide the latest estimates of the phylogeny for three species of Centropodia (C. forskalii (Vahl) T.A. Cope, C. glauca, C. mossamedensis (Rendle) T.A. Cope), Merxmuellera papposa, and $M$. rangei by analyzing seven markers from the plastid genome-rps3 (coding), rps16-trnK (intergenic spacer), rps16 intron, rpl32-trnL (intergenic spacer), $n d h F$ (coding), $n d h A$ intron, and matK (coding). To do this we added 111 new DNA sequences, primarily from $m a t K$, to an existing large molecular dataset investigating the phylogeny of Chloridoideae presented in Peterson \& al. (2010a). In addition, we report a new carbon isotope $\delta^{13} \mathrm{C}$ value for Merxmuellera papposa indicating it is $\mathrm{C}_{3}$ and verify earlier carbon isotope $\delta^{13} \mathrm{C}$ values for Centropodia glauca, C. mossamedensis, and Merxmuellera rangei. Based on our phylogenetic and morphological evidence we propose a new tribe, Centropodieae and a new genus, Ellisochloa.

\section{MATERIALS AND METHODS}

Morphological data. - Descriptions for the new tribe, Centropodieae and the new genus, Ellisochloa were prepared by consulting Clayton \& al. (2006) and observing herbarium specimens. TROPICOS (2010) and the Catalogue of New World grasses were also heavily used for deciphering nomenclatural problems (Peterson \& al., 2001; Soreng \& al., 2009).

Taxon sampling. - The Chloridoideae subset of data is partitioned to represent the following four major tribes: Triraphideae with three species, Eragrostideae with nine species, Zoysieae with seven species, and Cynodonteae with 64 species. A complete set of 13 subtribes within Cynodonteae is partitioned as: two species in Aeluropodinae, four species in Triodiinae, two species in Orcuttiinae, four species in Tridentinae, 22 species in Eleusininae, two species in the Pappophorinae, three species in Tripogoninae, four species in Traginae, one species in Hilariinae, three species in Monanthochloinae, one species in Boutelouinae, six species in Scleropogoninae, and 10 species in Muhlenbergiinae. Additionally, Chloridoideae include 13 species with uncertain taxonomic position. Outside of Chloridoideae the following six subsets of taxa were assembled: Chasmanthieae (Panicoideae) with three species, Aristidoideae with two species, Arundinoideae with two species, Micrairoideae with six species, Danthonioideae with 13 species, and Centropodieae with five species. In order to complete the subsets of Arundinoideae, Micrairoideae, and Danthonioideae we used GenBank accessions of $n d h F$ and matK sequences for the following genera: Austrodanthonia H.P. Linder, Chionochloa Zotov, Isachne R. Br., Karroochloa Conert \& Türpe, Micraira F. Muell., Molinia Schrank, and Phragmites Adans. Representatives of these subfamilies, tribes, and subtribes were chosen to adequately assess the position of Centropodia and the two species of Merxmuellera. The sequence data for all species of Centropodia and Merxmuellera are newly reported except for Merxmuellera macowanii (Stapf) Conert where we used existing data available from GenBank. A complete list of taxa in our analysis appears in the Appendix.

DNA extraction, amplification, and sequencing. - All procedures were performed in the Laboratory of Analytical Biology (LAB) at the Smithsonian Institution. DNA isolation, amplification, and sequencing of rps3, rpsl6-trnK intergenic spacer (IGS), rps16 intron, rpl32-trnL IGS, $n d h F$, and $n d h A$ intron for newly acquired specimens was accomplished following procedures outlined in Peterson \& al. (2010a, b). A 
portion of the $m a t K$ region (846 total aligned characters) was amplified and sequenced with the pair of primers matK-FORW (acgcagcgaccgcacgca) and matK-REV (actgactagtctcgagct) according to the following PCR thermo-cycle conditions: $95^{\circ} \mathrm{C}$ for $3 \mathrm{~min}$; followed by 35 cycles of $94^{\circ} \mathrm{C}$ for $40 \mathrm{~s}, 50^{\circ} \mathrm{C}$ for $40 \mathrm{~s}$, and $72^{\circ} \mathrm{C}$ for $1 \mathrm{~min} 40 \mathrm{~s}$; the temperature of the final extension was set for $72^{\circ} \mathrm{C}$ for $10 \mathrm{~min}$.

We excluded the widely used nrDNA ITS marker from our analyses because it was found to be of little utility in resolving basal nodes in the phylogeny of Chloridoideae (Peterson $\&$ al., 2010a). We assume that the inclusion of ITS data would only introduce more homoplasy to our phylogenetic hypotheses (see table 2 in Peterson \& al., 2010a where ITS has the highest homoplasy index of 0.791). Our choice of markers for this study was based on performance, i.e., which ones possessed a high number of variable characters that were parsimony-informative with low levels of homoplasy.

Phylogenetic analyses. - Sequences were aligned using BioEdit v.7.0.5.3 (Hall, 1999). The indels and ambiguously aligned regions were excluded from analyses while all gaps were treated as missing data. Three species of Chasmanthium Link representing Chasmanthieae were used as the outgroup (Appendix).

We used maximum likelihood and Bayesian analyses to infer phylogeny. Likelihood parameters were estimated with jModeltest v.0.1 (Posada, 2008) while choosing Akaike information criterion (AIC). The maximum parsimony method was employed to assess overall performance of each marker. Consistency, homoplasy, retention, and rescaled consistency indexes are reported in Table 1. The maximum likelihood analysis was performed using the program GARLI v.0.951 (Zwick1, 2006). Using AIC-specified models the maximum likelihood tree topologies for each chloroplast region were congruent in resolving major phylogenetic groups. Since GARLI does not allow data partitioning, bootstrap analysis (Felsenstein, 1985) for the combined dataset was run under a single model $(\mathrm{GTR}+\mathrm{G})$ with the default parameters set at 1000 replicates. The program PAUP* v.4.0b10 (Swofford, 2000) was used to compute the bootstrap majority-rule consensus tree. Bootstrap (BS) values of $90 \%-100 \%$ were interpreted as strong support, $70 \%-89 \%$ as moderate, and $50 \%-69 \%$ as weak.

Bayesian analysis was conducted with the program MrBayes v.3.1.2 (Huelsenbeck \& Ronquist, 2001). The overall dataset was partitioned according to the different evolutionary models. The maximum likelihood parameters were used in the fixed mode. Initially, the analysis was run for two million generations with a sample frequency set for 100 . An additional two million generations were added in order to complete the search. The analysis was continued until the convergence diagnostic (standard deviation of split sequences) dropped below 0.01 . The fraction of the sampled values discarded as burn-in was set at 0.25 . Posterior probabilities (PP) of $0.95-1.00$ were considered significant.

Carbon isotope ratio. - The $\mathrm{C}_{4}$ pathway is characterized by the fixation of atmospheric $\mathrm{CO}_{2}$ via coupling of carbonic anhydrase and phosphoenolpyruvate carboxylase, whereas in $\mathrm{C}_{3}$ plants fixation of $\mathrm{CO}_{2}$ is performed by ribulose-1,5-bisphosphate carboxylase. These two enzymes differentially discriminate among the naturally occurring carbon isotopes in the atmosphere, resulting in a different ${ }^{12} \mathrm{C} /{ }^{13} \mathrm{C}$ ratio as determined by mass spectrometry. Values of $\delta^{13} \mathrm{C}$ between -21 to $-32 \%$ indicate $C_{3}$ photosynthesis, whereas values between -9 to -16 indicate $\mathrm{C}_{4}$ photosynthesis (Von Caemmerer, 1992). Leaf $\delta^{13} \mathrm{C}$ values were determined for five herbarium samples (Table 2) housed at the Selmar Schonland Herbarium (GRA) in Grahamstown, South Africa. Isotope analyses were carried out at the IsoEnvironmental Isotope Facility at the Botany Department, Rhodes University. $\delta^{13} \mathrm{C}$ and $\delta^{15} \mathrm{~N}$ were determined on a Europa Scientific 20-20 mass spectrometer after sample combustion in an online ANCA SL preparation unit. Sucrose, Ammonium Sulphate, and Casein were used as internal standards, which were calibrated against the international reference materials IAEA-CH-6 and IAEA-N-1. Repeated analyses $(n=5)$ of homogeneous material yielded a standard deviation of $0.16 \%$ and $0.11 \%$ for $\delta^{15} \mathrm{~N}$ and $\delta^{13} \mathrm{C}$ respectively.

\section{口ESULTS}

Analysis of plastid sequences. - The total dataset includes 127 species and 709 sequences from the seven plastid regions (rps3, rpsl6-trnK IGS, rpsl6 intron, rpl32-trnL IGS, $n d h F, n d h A$ intron, $m a t K)$, of which, 111 are new (Appendix). The combined plastid analysis includes 7640 aligned nucleotide positions of which $2852(37 \%)$ are variable, and $1782(23 \%)$ are parsimony-informative (Table 1). The overall dataset includes $20.2 \%$ missing data. The rpl32-trnL region had the highest number of parsimony-informative characters at 349 , followed by rps 16-trnK and $n d h A$, both with 304 . The ratio of parsimonyinformative characters per total aligned characters was greatest for $n d h F(0.322)$ followed by $r p l 32$-trnL (0.251) and rps16-trnK (0.248).

Within Chloridoideae four lineages are recovered (Fig. 1): Cynodonteae $(\mathrm{BS}=85, \mathrm{PP}=1.00)$ and Zoysieae $(\mathrm{BS}=97, \mathrm{PP}$ $=1.00)$ are sister; sister to this clade are Eragrostideae $(\mathrm{BS}=$ $96, \mathrm{PP}=1.00)$; and sister to this clade are Triraphideae $(\mathrm{BS}=$ $100, \mathrm{PP}=1.00)$. Centropodieae $(\mathrm{BS}=100, \mathrm{PP}=1.00)$ are sister to the four tribes of Chloridoideae and together they form a strongly supported clade $(\mathrm{BS}=97, \mathrm{PP}=1.00)$. Sister to Chloridoideae and Centropodieae are Danthonioideae $(\mathrm{BS}=100$, PP $=1.00$ ), and together they form a weakly supported clade $(\mathrm{BS}=61, \mathrm{PP}=0.99)$. Micrairoideae $(\mathrm{BS}=100, \mathrm{PP}=1.00)$ and Arundinoideae ( $\mathrm{BS}=100, \mathrm{PP}=0.96$ ) are sister (unsupported) and together they are sister (unsupported) to Danthonioideae, Centropodieae, and Chloridoideae. Chasmanthieae (BS $=100$, $\mathrm{PP}=1.00)$, Aristidoideae $(\mathrm{BS}=100, \mathrm{PP}=1.00)$, and remaining taxa form an unsupported trichotomy.

Centropodia appears monophyletic, consisting of C. forskalii and C. glauca $(\mathrm{BS}=100, \mathrm{PP}=1.00)$ sister to $C$. mossamedensis $(\mathrm{BS}=100, \mathrm{PP}=1.00)$. Merxmuellera papposa and $M$. rangei form a strongly supported clade $(\mathrm{BS}=100, \mathrm{PP}$ $=1.00)$ and are sister to Centropodia $(\mathrm{BS}=100, \mathrm{PP}=1.00)$.

Carbon isotope ratios. - The $\delta^{13} \mathrm{C}$ values ranged between -13.41 and -28.68 for the five accessions (Table 2). Centropodia 
Table 1. Summary of seven plastid regions used in this study.

\begin{tabular}{|c|c|c|c|c|c|c|c|c|}
\hline Characteristic & rps 3 & rps16-trnK & rps16 & rpl32-trnL & $n d h F$ & $n d h A$ & matK & Combined \\
\hline No. of taxa & 101 & 104 & 99 & 104 & 113 & 93 & 94 & 127 \\
\hline Total aligned characters & 591 & 1223 & 1369 & 1390 & 796 & 1425 & 846 & 7640 \\
\hline Number of parsimony-informative characters* & 116 & 304 & 198 & 349 & 257 & 304 & 225 & 1782 \\
\hline Tree length & 449 & 1121 & 802 & 1522 & 1129 & 1124 & 837 & 7388 \\
\hline Homoplasy index $(\mathrm{HI})^{*}$ & 0.4989 & 0.3943 & 0.3641 & 0.4619 & 0.5430 & 0.3995 & 0.4612 & 0.4678 \\
\hline CI excluding uninformative characters* & 0.4074 & 0.5190 & 0.5109 & 0.4460 & 0.3845 & 0.5135 & 0.4556 & 0.4410 \\
\hline HI excluding uninformative characters* & 0.5926 & 0.4810 & 0.4891 & 0.5540 & 0.6155 & 0.4865 & 0.5444 & 0.5590 \\
\hline Retention index $(\mathrm{RI})^{*}$ & 0.6795 & 0.7477 & 0.7195 & 0.6633 & 0.7324 & 0.7397 & 0.7649 & 0.7007 \\
\hline Rescaled consistency index (RC)* & 0.3405 & 0.4529 & 0.4575 & 0.3569 & 0.3348 & 0.4442 & 0.4122 & 0.3729 \\
\hline
\end{tabular}

*These measures characterize a maximum parsimony analysis and are given to assess the overall performance of each region.

glauca, C. mossamedensis, and Merxmuellera rangei confirm previous conclusions that the former two species are $\mathrm{C}_{4}$ and the latter is $\mathrm{C}_{3}$ (Ellis, 1982, 1984b; Schulze \& al., 1996). Based on two $\delta^{13} \mathrm{C}$ values ranging from -27.74 to -28.68 , Merxmuellera papposa is reported to be $\mathrm{C}_{3}$ species.

\section{DISCUSSION}

Evolutionary relationships among the danthonioid members of Merxmuellera s.l. indicate that the eight species of Tenaxia are derived (reference node O, fig. 1 in Linder \& al., 2010) in comparison to those species retained in Merxmuellera s.str., Geochloa, and Capeochloa (basal grade) when using Centropodia and Ellisochloa (M. papposa, M. rangei) to polarize their cladograms. Therefore, 9-veined lemmas with adaxial surfaces bearing transverse rows of hair tufts, lemmas with deeply bilobed apices awned at the sinus, and spikelets with relatively long glumes found in Centropodia and Ellisochloa (M. papposa, M. rangei) are apparently plesiomorphic states since these characteristics are commonly found in Merxmuellera s.str., Geochloa, Capeochloa, and other members of Danthonioideae. Since the Merxmuellera papposa-M. rangei clade is sister to a monophyletic Centropodia composed of three species (Fig. 1) and the former pair is morphologically distinct with membranous glumes 1-3-veined, non-deciduous

Table 2. Stable carbon isotope ratios $\left(\delta^{13} \mathrm{C}\right)$ for leaf material from the following taxa.

\begin{tabular}{lll}
\hline Taxon & Collector \& number & $\delta^{13} \mathrm{C}$ \\
\hline Centropodia glauca & Linder 5410 & -13.75 \\
C. mossamedensis & Ward 10862 & -13.41 \\
Merxmuellera papposa & Barker \& Mafa 1760 & -28.68 \\
M. papposa & Barker \& Mafa 1759 & -27.74 \\
M. rangei & Barker 960 & -27.10 \\
\hline
\end{tabular}

leaf blades at the ligule, spikelets with non elongated rachilla internodes between the glumes, paleas as long as the lemmas, and completely distinct leaf anatomical characteristics, we accommodate these two species in a separate genus, Ellisochloa. Likewise, for consistency in recognizing monophyletic subfamilies, we place Ellisochloa and Centropodia in a new tribe, Centropodieae, in an expanded Chloridoideae.

The evolution of $\mathrm{C}_{4}$ photosynthesis has recently received renewed interest particularly in regards to grasses (Christin $\&$ al., 2010) and there have been many attempts to reconstruct $\mathrm{C}_{4}$ origins from $\mathrm{C}_{3}$ ancestors and reversions (Giussani \& al., 2001; Duvall \& al., 2003; Christin \& al., 2008, 2010; Vicentini \& al., 2008; Bouchenak-Khelladi \& al., 2009; Edwards \& al, 2010). Our phylogeny of Chloridoideae suggests the following two scenarios: $\mathrm{C}_{4}$ photosynthesis arose from $\mathrm{C}_{3}$ ancestors twice, once along the core clade (B in Fig. 1) and again along the Centropodia clade; or $\mathrm{C}_{4}$ photosynthesis arose once for the entire Chloridoideae (A in Fig. 1) and then was lost (reversal) in Ellisochloa (= Merxmuellera papposa-M. rangei clade). Christin \& al. (2010) have argued rather convincingly that the genetic cost of gaining the $\mathrm{C}_{4}$ pathway is high involving dozens of genes and therefore the reversal from $\mathrm{C}_{4}$ back to the $\mathrm{C}_{3}$ condition could not occur simply through loss of function and that reversals can only be proven by detecting genetic traces of $\mathrm{C}_{4}$ ancestry in present day $\mathrm{C}_{3}$ plants. Therefore, the easiest explanation, in line with Dollo's Law (reviewed in Collin \& Miglietta, 2008 and Christin \& al., 2010), is that $\mathrm{C}_{4}$ photosynthesis arose twice within Chloridoideae because reversal of such a complex suit of characters is unlikely. There appears to be no anatomical evidence of past $\mathrm{C}_{4}$ characteristics in Ellisochloa since the leaf blade in cross section has irregular, palisade-like chlorenchyma surrounding the vascular bundles (as opposed to radiate in most $\mathrm{C}_{4}$ grasses) and there are many mesophyll cells (as opposed to 1 or 2) separating adjacent vascular bundles (Ellis, 1982). However, both species of Ellisochloa possess terete leaves with adaxial surfaces reduced to a small groove; a clear adaption to water-use efficiency. 


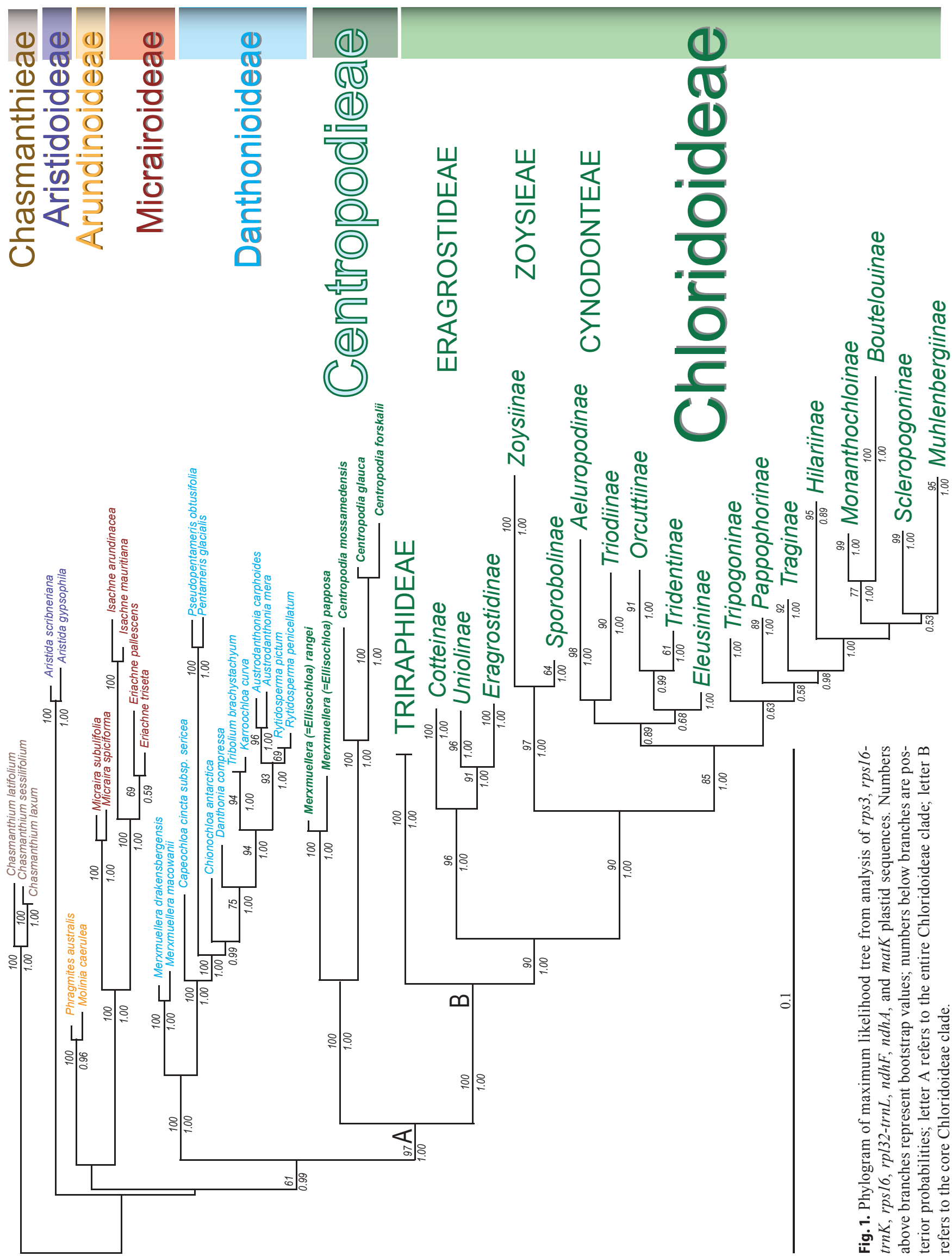


Centropodieae are distributed in Africa or temperate Asia and this supports the hypothesis that Chloridoideae might have originated in Africa and/or Asia since Ellisochloa and Centropodia share a common ancestor with Triraphideae, the next diverging lineage that includes sister genera, Neyraudia Hook. f. and Triraphis R. Br., both with African and Asian distribution. Neyraudia contains four species all native to Asia with N. arundinacea (L.) Henrard also occurring in tropical Africa (Clayton $\&$ al., 2006; Chen \& Phillips, 2006). Triraphis consists of eight species with six of these native to Africa; T. mollis R. Br. native to Australia, and T. devia Filg. \& Zuloaga native to South America (Filgueiras \& Zuloaga, 1999; Nightingale \& Weiller, 2005). The latter species is more than likely derived and recently dispersed to South America. Because more than half of the genera of Chloridoideae reside in Africa and the larger tribes, such as Eragrostideae, Zoysieae, and Cynodonteae, excluding Muhlenbergiinae, have centers of diversity there, Hartley \& Slater (1960) concluded that the subfamily probably originated on the African continent (during the Oligocene) and spread to other parts of the World.

\section{口 TAXONOMIC TREATMENT}

In the following paragraphs we present a description of a new tribe Centropodieae P.M. Peterson, N.P. Barker \& H.P Linder (subfam. Chloridoideae) and in this tribe we describe a new genus Ellisochloa P.M. Peterson \& N.P. Barker with two species: E. papposa (Nees) P.M. Peterson \& N.P. Barker and E. rangei (Pilg.) P.M. Peterson \& N.P. Barker.

Centropodieae P.M. Peterson, N.P. Barker \& H.P. Linder, tr. nov. - Type: Centropodia Rchb., Consp. Regn. Veg.: 212a. 1828. Included genera: Centropodia, Ellisochloa.

Triraphideae similis sed lemmatibus 9-nervatis, abaxialibus superficiebus lemmatum cum serie transversali caespitum 2-8 pilorum; lobis lemmatum apicalium $0.4-0.6$ plo longioribus quam lemmatibus; spiculis 2-6-florescentibus, differt.

Description. - Plants perennial, tufted or rhizomatous, cataphylls sometimes present. Culms 3-120 cm tall, erect, geniculately ascending or decumbent. Leaf sheaths pubescent near base, internodes mostly glaucous; ligule a fringe of hairs or a ciliate membrane; leaf blades $0.7-30.0 \mathrm{~cm}$ long, $1-8 \mathrm{~mm}$ wide, flat or involute, stiff, deciduous at the ligule, apices pungent. Panicles 2.5-30.0 cm long, $0.5-3.0 \mathrm{~cm}$ wide, contracted. Spikelets 7-24 mm long, lanceolate or cuneate, laterally compressed, 2-6-flowered, breaking up at maturity and disarticulating below each fertile floret; rachilla internodes sometimes elongated between glumes; callus pubescent, sometimes pilose, usually pungent; glumes 7-22 $\mathrm{mm}$ long, similar in length, shorter to longer than the spikelet, elliptic to lanceolate, chartaceous or membranous, persistent, 1-11-veined, not keeled, glabrous or pubescent, apices acute to acuminate; lemmas 4-11 mm long, oblong, chartaceous, 9-veined, with a transverse row of hair tufts, bearing $2-8$ hair tufts in all, pubescent, rarely glabrous between the veins, apex bilobed and awned between the lobes at the sinus, the lobes $0.4-0.6$ times as long as the lemma, the awn 3-18 mm long, with a geniculate, sometimes straight column; paleas as long or shorter than the lemma, 2-veined, keels ciliolate or not; stamens 3, anthers 1-5 mm long; lodicules 2, cuneate or truncate, fleshy, glabrous. Caryopsis with an adherent pericarp. Base chromosome number, $x=9,12$.

Leaf anatomy. - Leaves expanded or round with the adaxial surface reduced to a small groove, ribs and furrows present or absent. Vascular bundles of either two or three types, more or less elliptical, all with xylem and phloem. Bundles sheaths complete, in Ellisochloa with bundle sheath extensions. All vascular bundles associated with sclerenchyma strands, these connected with the bundle sheath extensions in the primary vascular bundles of Ellisochloa. Outer vascular bundle cells in Centropodia fan-shaped, in Ellisochloa round. Chlorenchyma in Centropodia radiate, and in Ellisochloa arranged in a dense, 3-5-layered palisade between the vascular bundles and epidermis. Central ground tissue in Ellisochloa of large clear cells. Adaxial epidermis elongate, rectangular long cells, with undulating walls, and files of low, dome-shaped or triangular stomata. Silica bodies round, vertically elongated, or dumbbell shaped, sometimes associated with cork cells. Microhairs not observed. $\mathrm{C}_{3}$ and $\mathrm{C}_{4}$ photosynthetic pathways.

Distribution. - A tribe of desert and dry-habitat Old World grasses, with one species in North Africa and to India, and five species in southern Africa.

\section{Key to the genera of Centropodieae}

1. Glumes 1-3-veined, membranous; leaf blades not deciduous at the ligule; rachilla internodes not elongated between the glumes; paleas as long as the lemmas .... Ellisochloa

1. Glumes 5-11-veined, chartaceous; leaf blades deciduous at the ligule; rachilla internodes elongated between the glumes; paleas $3 / 4$ as long as the lemmas ... Centropodia

Ellisochloa P.M. Peterson \& N.P. Barker, gen. nov. - Type: Danthonia rangei Pilg. in Bot. Jahrb. Syst. 43: 386. 1909 $\equiv$ Merxmuellera rangei (Pilg.) Conert in Senckenberg. Biol. 51: 133. 1970.

Centropodia Rchb. similis sed glumis 1-3-nervatis, membranaceis, paleis lemmata aequantibus, pilosis, differt.

Description. - Plants perennial, caespitose. Culms 12 $50 \mathrm{~cm}$ tall, erect. Leaf sheaths basally glabrous, sometimes papery; ligule a fringe of hairs; leaf blades $3.5-30.0 \mathrm{~cm}$ long, 1-3 mm wide, terete and filiform or flat to folded near base, apices sometimes pungent. Panicles $4-15 \mathrm{~cm}$ long, lanceolate to oblong, contracted. Spikelets 9-18 $\mathrm{mm}$ long, cuneate, laterally compressed, 2-3-flowered, breaking up at maturity and disarticulating below each fertile floret; callus pubescent or pilose; glumes 9-18 mm long, similar in length and 1.3-1.7 times the length of the lower floret, lanceolate, membranous, persistent, 1-3-veined, not keeled, apices acute to acuminate; lemmas 7-10 mm long, oblong, chartaceous, 9-veined, pubescent below with a transverse row of hair tufts, bearing 4-6 hair tufts in all, apex bilobed and awned between the lobes at the sinus, the lobes half as long as the lemma, the awn 9-18 $\mathrm{mm}$ long, geniculate with twisted column; paleas about the same 
length as the lemmas, pilose; stamens 3; lodicules 2, fleshy, glabrous, truncate. Base chromosome number, $x=9$.

Leaf anatomy. - Leaves circular in cross section with the adaxial surface reduced to a small groove, ribs and furrows on both surfaces vestigial or absent. Median vascular bundle not differentiated, three orders of vascular bundles, these alternating. Vascular bundles elliptical, all with xylem and phloem, and with proto- and metaxylem equivalent to inner bundle sheath cells. Inner bundle sheath somewhat thickened, thickened cells partially enclosing the phloem. Outer bundle sheath cells as large or larger than mesophyll cells, outer bundle sheath of the primary vascular bundes with adand abaxial extensions, the abaxial extensions connected to a sclerenchyma rib that reaches the epidermis. Adaxial extensions 3-5 cells deep, connected with large colorless cells in middle of leaf. All vascular bundles associated with sclerenchyma strands, but only the primary vascular bundles connected to the strands. Chlorenchyma irregular between the abaxial epidermis and the vascular bundles, palisade-like and ca. 4 cell layers deep. Mesophyll of large cells with spaces, colorless, forming the center of the leaf. Abaxial epidermis lacking prickles, macrohairs, bulliform cells, and microhairs. Stomata numerous, triangular in shape, either in adjacent rows, or rows separated by one row of thin-walled long cells. Stomata separated in a file by a single long cell, this scarcely longer than the stoma. Costal long cells separated by silico-suberose short cells, with crescent-shaped cork cells enclosing round silica bodies. $\mathrm{C}_{3}$ photosynthetic pathway.

Distribution and habitat. - Both species are endemic to southern Africa (Gibbs Russell \& al., 1990). Ellisochloa papposa is a rare grass from the Eastern Cape of South Africa, where it has been collected from between Uitenhague and Grahamstown. It is currently known only from a few localities in the upper catchment of the Gamtoos River (Kouga and Groot River Tributaries) where it grows on coarse alluvial sands, a habitat in common with that of $M$. rangei, which is endemic to southern Namibia where it is similarly of restricted distribution (found between Aus and the Orange River).

Notes. - Since the type of Merxmuellera is M. davyi (C.E. Hubb.) Conert and this is one of the currently recognized genera in the Danthonioideae (Linder \& al., 2010), a new generic name for M. papposa and M. rangei is needed. We name the new genus in honor of the South African agrostologist Dr. Roger P. Ellis (born 19 Dec 1944), who produced many fine papers on the leaf anatomy of grasses.

\section{Key to the species of Ellisochloa}

1. Panicles $12-15 \mathrm{~cm}$ long; lemmas $9-10 \mathrm{~mm}$ long, awns 15-18 mm long; glumes 13-18 mm long, apex acuminate E. papposa

1. Panicles 4-6 cm long; lemmas about $7 \mathrm{~mm}$ long, awns 9-10 mm long; glumes 9-12 mm long, apex acute.

\section{E. rangei}

Ellisochloa papposa (Nees) P.M. Peterson \& N.P. Barker, comb. nov. $\equiv$ Danthonia papposa Nees, Fl. Afr. Austral.
Ill.: 333. $1841 \equiv$ Merxmuellera papposa (Nees.) Conert in Senckenberg. Biol. 51: 133. 1970 - Lectotype (designated here): South Africa, Uitenhaag, Zwartkopsrivier, Thal und angrenzende Hügel von Villa Paul Maré bis Uitenhaag, C.F. Ecklon 137 (W-1889-0244838!, ex Reichenbach Herb., label with "137 Danthonia cincta N. ab E. 2.4 et 2.11"). Conert (1970) designated Ecklon s.n. as a lectotype but did not specify a particular specimen or herbarium where it was housed.

Ellisochloa rangei (Pilg.) P.M. Peterson \& N.P. Barker, comb. nov. $\equiv$ Danthonia rangei Pilg. in Bot. Jahrb. Syst. 43: 386. $1909 \equiv$ Merxmuellera rangei (Pilg.) Conert in Senckenberg. Biol. 51: 133. 1970 - Type: Southwest Africa, Oct 1906, Range 89 (holotype, B!; isotype, SAM).

\section{ACKNOWLEDGEMENTS}

We thank the National Geographic Society Committee for Research and Exploration (Grant No. 8087-06) for field and laboratory support; the Smithsonian Institution's, Restricted Endowments Fund, the Scholarly Studies Program, Research Opportunities, Atherton Seidell Foundation, Biodiversity Surveys and Inventories Program, Small Grants Program, and the Laboratory of Analytical Biology, all for financial support. We would also like to acknowledge Lee Weigt, Gabriel Johnson, Jeffery Hunt, and David Erickson for help in the laboratory; Robert J. Soreng, Jeffery M. Saarela, Carol R. Annable, and Nancy F. Refulio Rodriguez for accompanying the first author on numerous field expeditions; Robert J. Soreng for many extended discussions pertinent to the manuscript; Alain Touwaide for help preparing the Latin diagnoses; HPL and NPB would like to acknowledge the late Mr. Paseka Mafa, from whose M.Sc. thesis (University of Cape Town) on the anatomical information on Merxmuellera papposa was taken; and Lynn G. Clark and three anonymous reviewers for providing helpful comments on the manuscript.

\section{口 LITERATURE CITED}

Barker, N.P., Galley, C., Verboom, G.A., Gilbert, M. \& Linder, H.P. 2007. The phylogeny of the austral grass subfamily Danthonioideae: evidence from multiple data sets. Pl. Syst. Evol. 264: 135-156.

Barker, N.P., Linder, H.P. \& Harley, E.H. 1995. Polyphyly of Arundinoideae (Poaceae): Evidence from $r b c L$ sequence data. Syst. Bot. 20: 423-435.

Barker, N.P., Linder, H.P. \& Harley, E.H. 1999. Sequences of the grassspecific insert in the chloroplast rpoC2 gene elucidate generic relationships of the Arundinoideae (Poaceae). Syst. Bot. 23: 327-350.

Barker, N.P., Morton, C.M. \& Linder, H.P. 2000. The Danthonieae: Generic composition and relationships. Pp. 221-230 in: Jacobs, S.W.L. \& Everett, J. (eds.), Grasses: Systematics and evolution. Melbourne: CSIRO.

Bouchenak-Khelladi, Y., Salamin, N., Savolainen, V., Forest, F., Van de Bank, M., Chase, M.W. \& Hodkinson, T.R. 2008. Large multi-gene phylogenetic trees of the grasses (Poaceae): Progress towards complete tribal and generic level sampling. Molec. Phylog. Evol. 47: 488-505.

Bouchenak-Khelladi, Y., Verboom, G.A., Hodkinson, T.R., Salamin, N., Francois, O., Chonghaile, G.N. \& Savolainen, V. 2009. The 
origins and diversification of C4 grasses and savanna-adapted ungulates. Global Change Biol. 15: 2397-2417.

Chen, S.L. \& Phillips, S.M. 2006. 125. Neyraudia J.D. Hooker, Fl. Brit. India 7: 305. 1896 [“1897’']. Pp. 459-460 in: Wu, Z.Y., Raven, P.H. \& Hong, D.Y. (eds.), Flora of China: Poaceae, vol. 22. Beijing: Science Press; St. Louis: Missouri Botanical Garden Press.

Christin, P.A., Besnard, G., Samaritani, E., Duvall, M.R., Hodkinson, T.R., Savolainen, V. \& Salamin, N. 2008. Oligocene $\mathrm{CO}_{2}$ decline promoted $\mathrm{C}_{4}$ photosynthesis in grasses. Curr. Biol. 18: 1-7.

Christin, P.A., Freckleton, R.P. \& Osborne, C.P. 2010. Can phylogenetics identify $\mathrm{C}_{4}$ origins and reversals. Trends Ecol. Evol. 25: 403-409.

Christin, P.A., Salamin, N., Kellogg, E.A., Vicentini, A. \& Besnard, G. 2009. Integrating phylogeny into studies of $\mathrm{C}_{4}$ variation in the grasses. Pl. Physiol. 149: 82-87.

Clayton, W.D. \& Renvoize, S.A. 1986. Genera graminum: Grasses of the World. Kew Bull., Addit. Ser. 13: 1-389.

Clayton, W.D., Vorontsova, M.S., Harman, K.T. \& Williamson, H. (2006 onwards). GrassBase - The online World grass flora. Kew: The Board of Trustees, Royal Botanic Gardens, Kew. http://www .kew.org/data/grasses-db.html (accessed 17 Dec 2010).

Collin, R. \& Miglietta, M.P. 2008. Reversing opinions on Dollo's Law. Trends Ecol. Evol. 23: 602-609.

Columbus, J.T., Cerros-Tlatilpa, R., Kinney, M.S., Siqueiros-Delgado, M.E., Bell, H.L., Griffith, M.P. \& Refulio-Rodriguez, N.F. 2007. Phylogenetics of Chloridoideae (Gramineae): A preliminary study based on nuclear ribosomal internal transcribed spacer and chloroplast $t r n L-F$ sequences. Aliso 23: 565-579.

Conert, H.J. 1970. Merxmuellera, eine neue Gattung der Gramineen. Scheckenberg. Biol. 51: 129-133.

Conert, H.J. 1971. The genus Danthonia in Africa. Mitt. Bot. Staatssamml. München 10: 299-308.

Cope, T.A. 1982. Centropodia: An earlier name for Asthenatherum (Gramineae). Kew Bull. 37: 657-659.

Duvall, M.R., Saar, D.E., Grayburn, W.S. \& Holbrook, G.P. 2003 Complex transitions between $\mathrm{C}_{3}$ and $\mathrm{C}_{4}$ photosynthesis during evolution of Paniceae: A phylogenetic case study emphasizing the position of Steinchisma hians (Poaceae), a $\mathrm{C}_{3}-\mathrm{C}_{4}$ intermediate. Int. J. Pl. Sci. 164: 949-958.

Edwards, E.J., Osborne, C.P., Strömberg, C.A.E., Smith, S.A. \& $\mathrm{C}_{4}$ Grasses Consortium [Edwards, E.J., Osborne, C.P., Strömberg, C.A.E., Smith, S.A., Bond, W.J., Christin, P.A., Cousins, A.B., Duvall, M.R., Fox, D.L., Freckleton, R.P., Ghannoum, O., Hartwell, J., Huang, Y., Janis, C.M., Keeley, J.E., Kellogg, E.A., Knapp, A.K., Leakey, A.D.B., Nelson, D.M., Saarela, J.M., Sage, R.F., Sala, O.E., Salamin, N., Still, C.J. \& Tipple, B.]. 2010. The origins of $\mathrm{C}_{4}$ grasslands: Integrating evolutionary and ecosystem science. Science 328: 587-591.

Ellis, R.P. 1982. Leaf anatomy of South African Danthonieae (Poaceae). VII. Merxmuellera dura and M. rangei. Bothalia 14: 95-99.

Ellis, R.P. 1984a. Eragrostis walteri - a 1st record of non-Kranz anatomy in the subfamily Chloridoideae (Poaceae). S. African J. Bot. 3: $380-386$.

Ellis, R.P. 1984b. Leaf anatomy of South African Danthonieae (Poaceae). IX. Asthenatherum glaucum. Bothalia 15: 153-159.

Felsenstein, J. 1985. Confidence limits on phylogenies: An approach using the bootstrap. Evolution 39: 783-791.

Filgueiras, T.S. \& Zuloaga, F.O. 1999. A new Triraphis (Poaceae: Eragrostoideae) from Brazil: First record of a native species in the New World. Novon 9: 36-41.

Gibbs Russell, G.E., Watson, L. Koekemoer, M., Smook, L., Barker, N.P., Anderson, H.M. \& Dallwitz, M.J. 1990. Grasses of southern Africa. Mem. Bot. Surv. South Africa 58: 1-437.

Giussani, L.M., Cota-Sánchez, J.H., Zuloaga, F.O. \& Kellogg, E.A. 2001. A molecular phylogeny of the grass subfamily Panicoideae (Poaceae) shows multiple origins of $\mathrm{C}_{4}$ photosynthesis. Amer. J. Bot. 88: 1993-2012.
GPWG (Grass Phylogeny Working Group). 2001. Phylogeny and subfamilial classification of the grasses (Poaceae). Ann. Missouri Bot. Gard. 88: 373-457.

Hall, T.A. 1999. BioEdit: A user-friendly biological sequence alignment editor and analysis program for Windows 95/98/NT. Nucl. Acids Symp. Ser. 41: 95-98.

Hartley, W. \& Slater, C. 1960. Studies on the origin, evolution, and distribution of the Gramineae. III. The tribes of the subfamily Eragrostoideae. Austral. J. Bot. 8: 256-276.

Hilu, K.W. \& Alice, L.A. 2001. A phylogeny of Chloridoideae (Poaceae) based on matK sequences. Syst. Bot. 26: 386-405.

Hilu, K.W., Alice, L.A. \& Liang, H. 1999. Phylogeny of Poaceae inferred from matK sequences. Ann. Missouri Bot. Gard. 86: 835-851.

Huelsenbeck, J.P. \& Ronquist, F.R. 2001. MRBAYES: Bayesian inference of phylogenetic trees. Bioinformatics 17: 754-755.

Ingram, A.L., Christin, P.A. \& Osborne, C.P. 2011. Molecular phylogenies disprove a hypothesized $\mathrm{C}_{4}$ reversion in Eragrostis walteri (Poaceae). Ann. Bot. 107: 321-325.

Linder, H.P., Baeza, M., Barker, N.P., Galley, C., Humphreys, A.M., Lloyd, K.M., Orlovich, D.A., Pirie, M.D., Simon, B.K., Walsh, N. \& Verboom, G.A. 2010. A generic classification of the Danthonioideae (Poaceae). Ann. Missouri Bot. Gard. 97: 306-364.

Nightingale, M.E. \& Weiller, C.M. 2005. Triraphis. Pp. 424-426 in: Mallett, K. (ed.), Flora of Australia, vol. 44B. Melbourne: CSIRO.

Peterson, P.M., Columbus, J.T. \& Pennington, S.J. 2007. Classification and biogeography of New World grasses: Chloridoideae. Aliso 23: $580-594$

Peterson, P.M., Romaschenko, K. \& Johnson, G. 2010a. A classification of the Chloridoideae (Poaceae) based on multi-gene phylogenetics trees. Molec. Phylog. Evol. 55: 580-598.

Peterson, P.M., Romaschenko, K. \& Johnson, G. 2010b. A phylogeny and classification of the Muhlenbergiinae (Poaceae: Chloridoideae: Cynodonteae) based on plastid and nuclear DNA sequences. Amer. J. Bot. 97: 1532-1554.

Peterson, P.M., Soreng, R.J., Davidse, G., Filgueiras, T.S., Zuloaga, F.O. \& Judziewicz, E.J. 2001. Catalogue of New World grasses (Poaceae): II. subfamily Chloridoideae. Contr. U.S. Natl. Herb. 41: 1-255.

Philipson, M.N. 1977. Haustorial synergids in Cortaderia (Gramineae). New Zealand J. Bot. 15: 777-778.

Philipson, M.N. \& Connor, H.E. 1984. Haustorial synergids in danthonioid grasses. Bot. Gaz. 145: 78-82.

Pirie, M.D., Humphreys, A.M., Galley, C., Barker, N.P., Verboom, G.A., Orlovich, D., Draffin, S.J., Lloyd, K, Baeza, C.M., Negritto, M., Ruiz, E., Cota, J.H.S., Reimer, E. \& Linder, H.P. 2008. A novel supermatrix approach improves resolution of phylogenetic relationships in a comprehensive sample of danthonioid grasses. Molec. Phylog. Evol. 48: 1106-1119.

Posada, D. 2008. jModelTest model averaging. Molec. Biol. Evol. 25: $1253-1256$

Roodt-Wilding, R. \& Spies, J.J. 2006. Phylogenetic relationships in southern African chloridoid grasses (Poaceae) based on nuclear and chloroplast sequence data. Syst. Biodivers. 4: 401-415.

Sánchez-Ken, J.G. \& Clark, L.G. 2010. Phylogeny and a new tribal classification of the Panicoideae s.l. (Poaceae) based on plastid and nuclear sequence data and structural data. Amer. J. Bot. 97: $1732-1748$.

Sánchez-Ken, J.G., Clark, L.G., Kellogg, E.A. \& Kay, E.E. 2007. Reinstatement and emendation of subfamily Micrairoideae (Poaceae). Syst. Bot. 32: 71-80.

Schulze, E.D., Ellis, R., Schulze, W., Trimborn, P. \& Ziegler, H. 1996. Diversity, metabolic types and $\delta^{13} \mathrm{C}$ carbon isotope ratios in the grass flora of Namibia in relation to growth form, precipitation and habitat conditions. Oecologia 106: 352-369.

Soreng, R.J., Davidse, G., Peterson, P.M., Zuloaga, F.O., Judziewicz, E.J., Filgueiras, T.S. \& Morrone, O. 2009. Classification 
of New World grasses (Poaceae). http://www.tropicos.org/project webportal.aspx?pagename $=$ ClassificationNWG\&projectid $=10(\mathrm{ac}-$ cessed 17 Dec 2010).

Soreng, R.J. \& Davis, J.I. 1998. Phylogenetics and character evolution in the grass family (Poaceae): Simultaneous analysis of morphological and chloroplast DNA restriction site character sets. Bot. Rev. 64: 1-85.

Swofford, D.L. 2000. PAUP*: Phylogenetic analysis using parsimony (*and other methods), version 4. Sunderland, Massachusetts: Sinauer.

TROPICOS. 2010. Missouri Botanical Garden. http://www.tropicos .org (accessed 17 Dec 2010).

Verboom, G.A., Linder, H.P. \& Barker, N.P. 1994. Haustorial synergids: An important character in the systematics of danthonioid grasses (Arundinoideae: Poaceae). Amer. J. Bot. 81: 1601-1610.

Vicentini, A., Barber, J.C., Aliscioni, S.S., Guissani, L.M. \& Kel$\operatorname{logg}$, E.A. 2008. The age of the grasses and clusters of origins of $\mathrm{C}_{4}$ photosynthesis. Global Change Biol. 14: 1-15.

Von Caemmerer, S. 1992. Stable carbon isotope discrimination in $\mathrm{C}_{3}-\mathrm{C}_{4}$ intermediates. Pl. Cell Environm. 15: 1063-1072.

Watson, L. \& Dallwitz, M.J. 1992. The grass genera of the World. Wallingford, U.K.: CABI.

Zwickl, D.J. 2006. Genetic algorithm approaches for the phylogenetic analysis of large biological sequence datasets under the maximum likelihood criterion. Ph.D. dissertation, University of Texas, U.S.A.

\begin{abstract}
Appendix. List of specimens sampled, voucher (collector, number, and where the specimen is housed), country of origin (abbreviations follow http://www .worldatlas.com/aatlas/ctycodes.htm), and GenBank accessions for DNA sequences in the order of rps3, rps16-trnK, rps16, rpl32-trnL, ndhF, ndhA, and $m a t K$. Sequences generated for this study are in bold type; a dash (-) indicates that region was not sequenced.
\end{abstract}

CHASMANTHIEAE: Chasmanthium latifolium (Michx.) H.O. Yates, Peterson 22463 (US), USA, GU360097, GU360517, GU360438, GU359891, GU359720, GU359379, -; Chasmanthium laxum (L.) H.O. Yates, Kanal 694 (US), USA, GU360050, GU360516, GU360437, GU359875, GU359721, GU359405, JF729094; Chasmanthium sessiliflorum (Poir.) H.O. Yates, Peterson 20823 \& Saarela(US), USA, -, GU360515, GU360436, GU359874, GU359722, GU359378, -; ARISTIDOIDEAE: Aristida gypsophila Beetle, Peterson 15839 \& Valdes-Reyna (US), MEX, GU360091, GU360570, GU360286, GU359977, -, GU359386, JF729083; Aristida scribneriana Hitchc., Peterson 15985 \& Gonzalez-Elizondo (US), MEX, GU360092, GU360569, GU360314, GU360010, -, GU359412, JF729084; ARUNDINOIDEAE: Molinia caerulea (L.) Moench, Borsch 3320, DEU, -, -, -, -, -, -, AF164411; Molinia caerulea (L.) Moench, Soreng 3305 (US), -,-,-,-, GU222716, -, -; Phragmites australis (Cav.) Steud., Fleming s.n., USA, -, -, -, -, -, -, AF144575; Phragmites australis (Cav.) Steud., Saarela $264 \&$ Farreira (UBC), CAN, -, -,-,-, EF422913,-, -; MICRAIROIDEAE: Eriachne pallescens R. Br., Singeo 26650 (US), PLW, -, JF729077,-, JF729177, JF729170,-,-; Eriachne triseta Nees, -, -, -, -, AM849155, -, -; Isachne arundinacea Griseb., -, -, -, -, AY847119, -, -; Isachne mauritiana Kunth, Besnard (G), -, -, -, -, AM849162, -, -; Micraira lazaridis L.G. Clark, J.F. Wendel \& Craven, -, -, -, -, U21972, -, -; Micraira spiciforma Lazarides, Jacobs 8850 (NSW), AUS, -, -, -, -, AM849166, -, -; DANTHONIOIDEAE: Austrodanthonia carphoides (Benth.) H.P. Linder, Linder 5568 (CHR), AUS, -, EU400770, -, EU400714; Austrodanthonia mera (Connor \& Edgar) H.P. Linder, Humphreys 86 (Z), AUS, -, -, -, -, EU400771, -, EU400715; Danthonia compressa Austin, Peterson 21986 \& Levine (US), USA, GU360040, GU360521, GU360483, GU359865, GU359688, GU359370, JF729103; Chionochloa antarctica (Hook.f.) Zotov, Lloyd 57955 (OTA), NZL, -, -,-,-, EU400774, EU400718; Karroochloa curva (Nees) Conert \& Türpe, Verboom 604 (BOL), ZAF, , EU400791, -, EU400735; Merxmuellera drakensbergensis (Schweikerdt) Conert, Mafa 4 (GRA), ZAF, JF729179, JF729078, JF729183, -, JF729171, JF729165, JF729123; Capeochloa cincta subsp. sericea (N.P. Barker) H.P. Linder, Barker 1545 (GRA), ZAF, -, JF729074, JF729181, JF729173, JF729167, JF729163, JF729090; Merxmuellera macowanii (Stapf) Conert, Barker 1008 (BOL), ZAF, -, -, -, -, EU400801, -, EU400745; Pseudopentameris obtusifolia (Hochst.) N.P. Barker, Barker 1668 (GRA), ZAF, -, -, -, -, EU400817, -, EU400762; Pentameris glacialis N.P. Barker, Linder 5498 (BOL), ZAF, --,

EU400807,-, EU400752; Rytidosperma penicellatum (Labill.) Connor \& Edgar, Peterson 19685, Saarela \& Sears (US), USA, GU360219, GU360671, GU360291, GU359984, GU359606, GU359518, JF729140; Rytidosperma pictum var. pictum (Nees \& Meyen) Nicora, Peterson 19182, Soreng, Salariato \& Panizza (US), ARG, GU360172, GU360655, GU360292, GU359983, GU359607, GU359527, JF729141; Tribolium brachystachyum (Nees) Renvoize, Verboom 593 (BOL), ZAF, -, -, -,-, EU400823, -, EU400768; CENTROPODIEAE: Centropodia forskalii (Vahl) Cope, Bornmüller 11082 (US), EGY, -,-,-, JF729174, -,

Centropodia glauca (Nees) Cope, Davidse 6367 (US), ZAF, -, JF729075, -, JF729175, JF729168, JF729164, JF729091; Centropodia mossamedensis (Rendle) Cope, Schweickerdt 2250 (US), ZAF, JF729178, JF729076, JF729182, JF729176, JF729169, -, JF729092; Merxmuellera rangei (Pilg.) Conert, Barker 960 (BOL), NAM, JF729180, JF729079, JF729184, -, JF729172, JF729166, JF729124; Merxmuellera papposa (Nees) Conert, Barker 1759 (GRA), ZAF, -, -, -, -, EU400802, -, EU400746; CHLORIDOIDEAE: Allolepis texana (Vasey) Soderstr. \& H.F. Decker, Hitchcock 7541 (US), MEX, GU360088, GU360573, GU360318, GU360015, GU359577, GU359388, JF729082; Bewsia biflora (Hack.) Gooss., Davidse 6471, Simon, Drummond \& Bennett (US), ZAF, GU360084, GU360564, GU360294, GU359858, GU359583, -, -; Brachychloa schiemanniana (Schweick.) S.M. Phillips, Schweickerdt 1911 (US), Africa, GU360117, GU360582,-, GU359881, GU359776,-,-; Dactyloctenium aegyptium (L.) Willd., Peterson 22283 \& Saarela (US), MEX, GU360122, GU360587, GU360432, GU359886, GU359713, GU359351, JF729102; Dignathia villosa C.E. Hubb., Ellis 204 (US), ETH, GU360037, GU360519, GU360480, GU359820, GU359691, GU359367, -; Gymnopogon grandiflorus Roseng., B.R. Arill. \& Izag., Peterson 16642 \& Refulio-Rodriguez (US), PER, GU360057, GU360581, GU360383, GU359816, GU359733, GU359436, JF729116; Jouvea pilosa (J. Presl) Scribn., Peterson 11017 \& Annable (US), MEX, GU360173, GU360696, GU360379, GU359812, GU359737, GU359433, JF729118; Mosdenia phleoides (Hack.) Stent, Schweickerdt 1542 (US), ZAF, GU360216, GU360681, GU360420, GU359967, GU359750, GU359458, JF729128; Neobouteloua lophostachya (Griseb.) Gould, Peterson 11515 \& Annable (US), ARG, GU360262, GU360725, GU360273, GU360004, GU359635, GU359396, JF729132; Perotis hordeiformis Nees, Soreng 5717, Peterson \& Sun Hang (US), CHN, GU360243, GU360708, GU360283, GU359991, GU359600, GU359520, JF729138; Sohnsia filifolia (E. Fourn.) Airy Shaw, Reeder 4073 \& Reeder (US), MEX, GU360165, GU360633, GU360332, GU359917, GU359614, GU359532, JF729144; Trichoneura weberbaueri Pilg., Peterson 15686 \& Soreng (US), CHL, GU360194, GU360668, GU360361, GU359948, GU359681, GU359565, JF729151; Urochondra setulosa (Trin.) C.E. Hubb., Rechinger 27496 (US), PAK, GU360178, GU360647, -, -

TRIRAPHIDEAE: Neyraudia reynaudiana (Kunth) Keng ex Hitchcock, Soreng 5318 \& Peterson (US), CHN, GU360263, -, GU360272, GU360003, GU359636, GU359397, JF729133; Triraphis mollis R. Br., Peterson 14344, Soreng \& Rosenberg (US), AUS, GU360185, GU360669, GU360336, GU359933, GU359650, GU359539, JF729156; Triraphis ramosissima Hack., Seydel 4278(US), ZAF, GU360183, GU360651, GU360338, GU359931, GU359652, GU359541, JF729157; ERAGROSTIDEAE: Cotteinae: Cottea pappophoroides Kunth, Peterson 21463, Soreng, LaTorre \& Rojas Fox (US), PER, GU360138, GU360600, GU360456, GU359842, GU359579, GU359363, JF729098; Enneapogon desvauxii P. Beauv., Peterson 21999 \& Saarela (US), MEX, GU360030, GU360495, GU360486, GU359796, GU359699, GU359474, JF729108; Uniolinae: Entoplocamia aristulata (Hack. \& Rendle) Stapf, Seydel 187 (US), ZAF, GU360027, GU360492, GU360468, GU359793, GU359702, GU359469, JF729110; Tetrachne dregei Nees, Jarman 120 (US), ZAF, -, GU360622, GU360365, GU359904, GU359670, GU359513, -; Uniola condensata Hitchc., Peterson 9342 \& Judziewicz (US), ECU, GU360180, GU360649, GU360340, GU359927, GU359654, GU359534, JF729158; Uniola paniculata L., Peterson 11160, Annable \& Valdes-Reyna (US), USA, GU360179, GU360648, GU360341, GU359926, GU359655, GU359543, JF729159; Eragrostidinae: Eragrostis intermedia Hitchc., Peterson 22302 \& Saarela(US), MEX, GU360078, GU360536, GU360399, GU359818, GU359762, GU359501, JF729111; Eragrostis minor Host, Peterson 19739, Saarela \& Sears (US), USA, GU360065, GU360527, GU360390, GU359824, GU359771, GU359475, JF729112; Psammagrostis wiseana C.A. Gardner \& C.E. Hubb., Peterson 14345, Soreng \& Rosenberg (US), AUS, GU360237, GU360703, GU360288, GU359986, GU359615, GU359533, JF729139; ZOYSIEAE: Zoysiinae: Zoysia japonica Steud., Kuragadake s.n. (US), JPN, GU360022, GU360643, -, GU359923, GU359658, GU359547, -; Zoysia macrantha Desv., Soreng 5913 \& Peterson (US), AUS, GU360020, GU360641, GU360346, GU360017, GU359660, GU359558, JF729162; Sporobolinae: Crypsis aculeata (L.) Aiton, Soreng 5469 \& Peterson (US), CHN, GU360140, GU360599, GU360402, GU359841, 
GU359573, GU359362, JF729099; Crypsis schoenoides (L.) Lam., Peterson 19814, Saarela \& Sears (US), USA, GU360141, GU360598, GU360455, GU359840, GU359574, GU359361, JF729100; Pogoneura biflora Napper, Greenway 10620, Turner \& Watson (US), TZA, GU360239, GU360704, -, GU359987, -, Sporobolus atrovirens (Kunth) Kunth, Peterson 22342 \& Saarela (US), MEX, GU360163, GU360632, GU360315, GU359915, -, GU359508, JF729145; Sporobolus indicus (L.) R. Br., Peterson 22025 \& Saarela (US), MEX, GU360161, GU360630, GU360355, GU359913, GU359637, GU359504, JF729146; CYNODONTEAE: Aeluropodinae: Aeluropus lagopoides (L.) Trin. ex Thwaites, Weinert s.n. \& Mosawi (US), IRQ, GU360085, GU360576, GU360284, GU360013, GU359591, GU359391,-; Aeluropus littoralis (Gouan) Parl., Ferguson 634 (US), GRC, GU360086, GU360575, GU360308, GU360018, GU359590, GU359390,

; Triodiinae: Orinus kokonorica (K. S. Hao) Keng ex X. L. Yang, Soreng 5447, Peterson \& Sun Hang (US), CHN, GU360259, GU360728, GU360270, GU359999, GU359628, GU359399, JF729134; Orinus thoroldii (Stapf ex Hemsely) Bor, Soreng 5515, Peterson \& Sun Hang (US), CHN, GU360257, GU360721, GU360269, GU359998, GU359626, GU359400, JF729135; Triodia basedowii Pritz., Peterson 14437, Soreng \& Rosenberg (US), AUS, GU360205, GU360666, GU360322, GU359946, GU359683, GU359550, JF729153; Triodia irritans var. laxispicata N.T. Burb., Hind 5731, D'Aubert \& Jones (US), AUS, GU360202, GU360660, GU360328, GU359940, GU359643, GU359564, JF729154; Orcuttiinae: Orcuttia tenuis Hitchc., Stone 771 (US), USA, -, GU360727, GU360271, GU360001, -, GU359398, -; Tuctoria greenei (Vasey) Reeder, Reeder 6656 \& Reeder (US), USA, GU360181, -, -, GU359928, -, -, -; Tridentinae: Gouinia paraguayensis (Kuntze) Parodi, Peterson 11526 \& Annable (US), ARG, GU360058, GU360504, GU360384, GU359817, GU359732, GU359437, JF729115; Tridens muticus (Torr.) Nash, Peterson 21997 \& Saarela (US), MEX, GU360195, GU360667, GU360321, GU359947, GU359682, GU359557, JF729152; Triplasis purpurea (Walter) Chapm., Peterson 14238, Weakley \& LeBlond (US), USA, GU360196, GU360656, GU360347, GU359921, GU359647, GU359536, JF729155; Vaseyochloa multinervosa (Vasey) Hitchc., Swallen 10041 (US), USA, GU360177, GU360646, GU360342, GU359925, GU359656, GU359544, JF729160; Eleusininae: Acrachne racemosa (B. Heyne ex Roem. \& Schult.) Ohwi, Smook 9899 (US), ZAF, GU360099, -, -, -, -, -, JF729080; Apochiton burttii C.E. Hubb., Greenway 11513 \& Polhill (US), TZA, GU360090, GU360571, GU360316, -, GU359594, -, -; Astrebla lappacea (Lindl.) Domin, McKinlay s.n. (US), AUS, GU360094, GU360568, GU360312, GU360009, GU359586, GU359395, JF729085; Austrochloris dichanthioides (Everist) Lazarides, Anson s.n. (US), AUS, GU360113, GU360566, GU360310, GU359860, GU359584, GU359420, JF729086; Brachyachne patentiflora (Stent \& Rattray) C.E. Hubb., Laegaard 16295 (US), ZWE, GU360119, GU360584, GU360458, GU359883, GU359708, GU359374, JF729089; Chloris radiata (L.) Sw., Peterson 22278 \& Saarela (US), MEX, GU360048, GU360513, GU360434, GU359872, GU359724, GU359366, JF729095; Chrysochloa hindsii C.E. Hubb., Reekmans 11068 (US), BDI, GU360044, GU360509, GU360485, GU359868, GU359728, -, -; Cleistogenes squarrosa (Trinius) Keng, Soreng 5156 \& Peterson (US), CHN, GU360136, GU360603, GU360473, GU359845, GU359566, GU359393, JF729096; Coelachyrum poiflorum Chiov., Burger 2915 (US), ETH, GU360129, GU360601, GU360457, GU359843, -, -, JF729097; Cynodon maritimus Kunth, Howard 10214 \& Howard (US), BHS, GU360126, GU360591, GU360448, GU359889, GU359710, GU359365, JF729101; Dinebra retroflexa (Vahl) Panz., Ndegwa 610 (US), KEN, GU360052, GU360503, GU360479, GU359778, GU359692, GU359355, JF729105; Eleusine indica (L.) Gaetrn., Peterson 21362, Saarela \& Flores Villegas (US), MEX, GU360031, GU360496, GU360472, GU359797, GU359698, GU359473, JF729107; Enteropogon ramosus B.K. Simon, Peterson 14367, Soreng \& Rosenberg (US), AUS, GU360028, GU360493, GU360469, GU359794, GU359701, GU359470, JF729109; Eustachys distichophylla (Lag.) Nees, Fowler s.n. (US), IDN, GU360061, GU360523, GU360387, GU359805, GU359742, GU359440, JF729114; Leptochloa dubia (Kunth) Nees, Peterson 22334 \& Saarela (US), MEX, GU360051, GU360695, GU360416, GU359811, GU359738, GU359442, JF729119; Lepturus gasparricensis Fosberg, Herbst 9687 (US), USA Wake Island, GU360230, GU360692, GU360429, GU359807, GU359741, GU359477, JF729120; Lintonia nutans Stapf, Mwasumbi 14374 (US), TZA, GU360226, GU360690, GU360427, GU359980, GU359743, GU359426, JF729121; Microchloa caffra Nees, Smook 10441 (US), ZAF, GU360206, GU360670, GU360424, GU359972, GU359746, GU359453, JF729125; Schoenefeldia transiens (Pilg.) Chiov., Greenway 9781 (US), KEN, GU360168, GU360636, GU360349, GU360007, GU359610, -, -; Saugetia fasciculata Hitchc. \& Chase, Ekman s.n. (US), DOM, GU360171, GU360638, GU360317, GU359982, GU359608, GU359528, -; Tetrapogon villosus Desf., Johannes s.n. (US), ES-CN, GU360151, GU360619, GU360367, GU359901, GU359684, GU359514, JF729148; Trichloris pluriflora E. Fourn., Peterson 15048 \& Refulio-Rodriguez (US), PER, GU360192, GU360623, GU360334, GU359905, GU359680, GU359554, JF729150; Tripogoninae: Eragrostiella leioptera (Stapf) Bor, Chand 7961 (US), IND, GU360066, GU360529, -, GU359827, GU359769, GU359486, -; Melanocenchris monoica (Rottler) C.E.C. Fisch., Clayton 5634 (US), LKA, -, GU360686, -, GU359974, -, -, -; Tripogon spicatus (Nees) Ekman, Peterson 21784 \& Soreng (US), PER, GU360188, GU360640, GU360333, GU359935, GU359648, GU359537, -; Pappophorinae: Neesiochloa barbata (Nees) Pilg., Swallen 4491 (US), BRA, GU360261, GU360724, GU360279, GU360005, GU359634, -, -; Pappophorum pappiferum (Lam.) Kuntze, Peterson 21689, Soreng, La Torre \& Rojas Fox (US), PER, GU360248, GU360700, GU360276, GU359996, GU359596, GU359402, JF729136; Traginae: Monelytrum luederitzianum Hack., Smook 10031 (US), ZAF, GU360218, GU360682, GU360421, GU359969, GU359749, GU359459, JF729127; Polevansia rigida De Winter, Smook 6000 (US), ZAF, GU360238, -, GU360287, -, GU359602, GU359523, -; Tragus pedunculatus Pilg., Schweickerdt 2297 (US), ZAF, GU360189, GU360613, GU360373, GU359895, GU359678, GU359552, JF729149; Willkommia texana Hitchc., Gould 12525 (US), USA, GU360054, GU360644, GU360344, -, -, GU359546, JF729161; Hilariinae: Hilaria cenchroides Kunth, Peterson 22339 \& Saarela (US), MEX, GU360055, GU360697, GU360380, GU359813, GU359736, GU359424, JF729117; Monanthochloinae: Distichlis humilis Phil., Peterson 19362, Soreng, Salariato \& Panizza (US), ARG, GU360035, GU360502, GU360478, GU359835, GU359693, GU359430, JF729106; Monanthochloe littoralis Engelm., Moran 10570 (US), MEX, GU360235, GU360699, GU360422, GU359970, GU359748, GU359460, JF729126; Reederochloa eludens Soderstr. \& H.F. Decker, Reed 6430 (US), MEX, GU360158, GU360701, GU360290,-,-,-, -; Boutelouinae: Bouteloua aristidoides (Kunth) Griseb., Peterson 21994 \& Saarela (US), MEX, GU360104, GU360558, GU360304, GU359852, GU359570, GU359417, JF729088; Scleropogoninae: Blepharidachne bigelovii (S. Watson) Hack., Johanston 9401 (US), MEX, GU360101, GU360562, GU360307, GU359856, GU359581, -, -; Dasyochloa pulchella (Kunth) Willd. ex Rydb., Peterson 21992 \& Saarela (US), MEX, GU360039, GU360505, GU360482, GU359864, GU359689, GU359369, JF729104; Erioneuron avenaceum (Kunth) Tateoka, Peterson 19329, Soreng, Salariato \& Panizza (US), ARG, GU360063, GU360525, GU360403, GU359822, GU359773, GU359441, JF729113; Munroa andina Phil., Peterson 19552, Soreng, Salariato \& Panizza (US), ARG, GU360251, GU360722, -, GU359965, GU359632, GU359394, JF729131; Scleropogon brevifolius Phil., Peterson 19280, Soreng, Salariado \& Panizza (US), ARG, GU360167, GU360635, -, GU359919, GU359611, GU359530, JF729143; Swallenia alexandrae (Swallen) Soderstr. \& H.F. Decker, Carter 2784 (US), USA, GU360154, GU360639, GU360364, GU359920, GU359669, GU359512, JF729147; Muhlenbergiinae: Muhlenbergia uniseta (Lag.) Columbus, Peterson 22044 \& Saarela (US), MEX, GU360128, GU360577, GU360278, GU360012, GU359592, GU359392, JF729081; Muhlenbergia biloba Hitchc., Peterson 7946, Annable \& Herrera (US), MEX, GU360098, GU360550, GU360309, GU359859, Muhlenbergia shepherdii (Vasey) Swallen, Peterson 22452 \& Saarela (US), MEX, GU360102, GU360560, GU360320, GU359854, GU359580, GU359419, JF729087; Muhlenbergia subbiflora Hitchc., Peterson 21158, Saarela, Rosen \& Reid (US), MEX, GU360036, GU360518, GU360439, GU359877, GU359707, GU359428, JF729093; Muhlenbergia alopecuroides (Griseb.) P.M. Peterson \& Columbus, Peterson 20960, Saarela, Lara Contreras \& Reyna Alvarez (US), MEX, GU360224, GU360688, GU360426, GU359976, GU359744, GU359425, JF729122; Muhlenbergia ramulosa (Kunth) Swallen, Peterson 22447 \& Saarela (US), MEX, GU360254, GU360717, GU360406, GU359953, GU359627, GU359444, JF729129; Muhlenbergia schreberi J.F. Gmel., Peterson 19443, Soreng, Salariato \& Panizza (US), ARG, GU360214, GU360679, GU360404, GU359950, GU359765, GU359456, JF729130; Muhlenbergia plumiseta Columbus, Peterson 20106, Hall, Alvarez Marvan \& Alvarez Jimenez (US), MEX, GU360246, GU360719, GU360281, GU359979, GU359598, GU359516, JF729137; Muhlenbergia multiflora Columbus, Peterson 7845 \& Annable (US), USA, GU360191, GU360702, GU360289, GU359985, GU359604, GU359525, -; Muhlenbergia paniculata (Nutt.) Columbus, Peterson 12070 \& Annable (US), USA, GU360170, GU360673, GU360375, GU359936, GU359609, GU359529, JF729142. 